\title{
Mesozoic and Cenozoic Cooling History of the Qiangtang Block, Northern Tibet, China: New Constraints from Apatite and Zircon Fission Track Data
}

\author{
Chunyan Song ${ }^{1,2,3}$, Jian Wang ${ }^{1,3, *}$, Xiugen $\mathrm{Fu}^{1,3}$, and $\mathrm{Li} \mathrm{He}^{1}$ \\ ${ }^{1}$ Chengdu Institute of Geology and Mineral Resources, Chengdu, China \\ ${ }^{2}$ Graduate Department of the Chinese Academy of Geological Sciences, Beijing, China \\ ${ }^{3}$ Key Laboratory for Sedimentary Basin and Oil and Gas Resources, Ministry of Land and Resources, Chengdu, China
}

Received 6 March 2012, accepted 5 July 2013

\begin{abstract}
This study used a new set of zircon and apatite fission track ages to quantitatively document the tectonic evolution and cooling histories of the Qiangtang block of the central Tibetan Plateau. The results indicate that the Qiangtang block underwent three cooling stages at $\sim 148-73, \sim 50-20$, and $\sim 20$ - 0 Ma. The three-stage cooling history and tectonic exhumation were controlled by the closure of the Bangong-Nujiang Suture during the Late Jurassic-Late Cretaceous, the India-Asia collision in the Paleogene, and the underthrusting of the India Plate during the Late Cenozoic. In addition to revealing the Late JurassicLate Cretaceous cooling events, the annealing patterns of the zircon fission track samples indicate different burial depths, which may help identify the Jurassic basin characteristics of the Qiangtang block. The apatite fission track (AFT) ages range from $60 \pm 5$ Ma to $26 \pm 3 \mathrm{Ma}$, with a mean age of $44 \mathrm{Ma}$. These ages indicate that the Cenozoic exhumation of the Qiangtang block may have started in the Eocene. Inverse modeling of the AFT data shows that the Qiangtang block had a relatively slow cooling rate of approximately $0.5-1^{\circ} \mathrm{C} \mathrm{Myr}^{-1}$ from 50 to $20 \mathrm{Ma}$. After $\sim 20 \mathrm{Ma}$, most of the samples show evidence for a rapid cooling stage with a cooling rate of $4-6^{\circ} \mathrm{C} \mathrm{Myr}^{-1}$.
\end{abstract}

Key words: Exhumation history, Cooling event, Fission track, Qiangtang block, Tibetan Plateau

Citation: Song, C., J. Wang, X.Fu, and L. He, 2013: Mesozoic and Cenozoic cooling history of the Qiangtang block, northern Tibet, China: New constraints from apatite and zircon fission track data. Terr. Atmos. Ocean. Sci., 24, 985-998, doi: 10.3319/TAO O.2013.07.05.02(TT)

\section{INTRODUCTION}

The Qiangtang block is located in the central Tibetan Plateau and is bounded by the Jinshajiang suture to the north and the Bangong-Nujiang suture to the south (Dewey et al. 1988; Yin and Harrison 2000) (Fig. 1). Because of its unique geographic and geological setting, the Qiangtang block has attracted geologists from around the world. Recent studies have included studies of the crystalline basement (Wang and Wang 2001; Tan et al. 2009; Wang et al. 2009; Guynn et al. 2012) and crust structure (Rodgers and Schwartz 1998; Unsworth et al. 2004; Li et al. 2006; Zhang et al. 2011), the metamorphic rocks of the central Qiangtang block (Kapp et al. 2003; Zhang et al. 2006; Zhai et al. 2007, 2011), Mesozoic volcanic rocks (Wang et al. 2008; Fu et al. 2010; Zhai et al. 2010; Zhang et al. 2011), Cenozoic volcanic rocks (Mo

\footnotetext{
* Corresponding author

E-mail:w1962jian@163.com
}

et al. 2006; Ding et al. 2007), oil shale (Fu et al. 2011a, b) and petroleum exploration in the Mesozoic basin ( $\mathrm{Li}$ et al. 2001; Wang et al. 2001; Wang et al. 2004; Guo et al. 2008; Wang et al. 2009). Sedimentary studies show that the formation and closure of the Mesozoic Qiangtang basin were closely connected with the tectonic evolutionary processes in the Bangong-Nujiang Ocean (Wang et al. 2004, 2009; Zhang et al. 2009). Evidence from thermochronology and Cenozoic volcanics indicates that the surface uplift of the Qiangtang block was mainly controlled by the India-Asia collision (Wang et al. 2007; Wang et al. 2008).

However, some questions remain unanswered: (1) Was Qiangtang a foreland basin (Li et al. 2001; Wang et al. 2001) or passive marginal basin (Wang et al. 2004; Guo et al. 2008; Wang et al. 2009) during the late Triassic-Jurassic period? The late Triassic-Jurassic basin in Qiangtang is an important marine basin with good petroleum exploration 


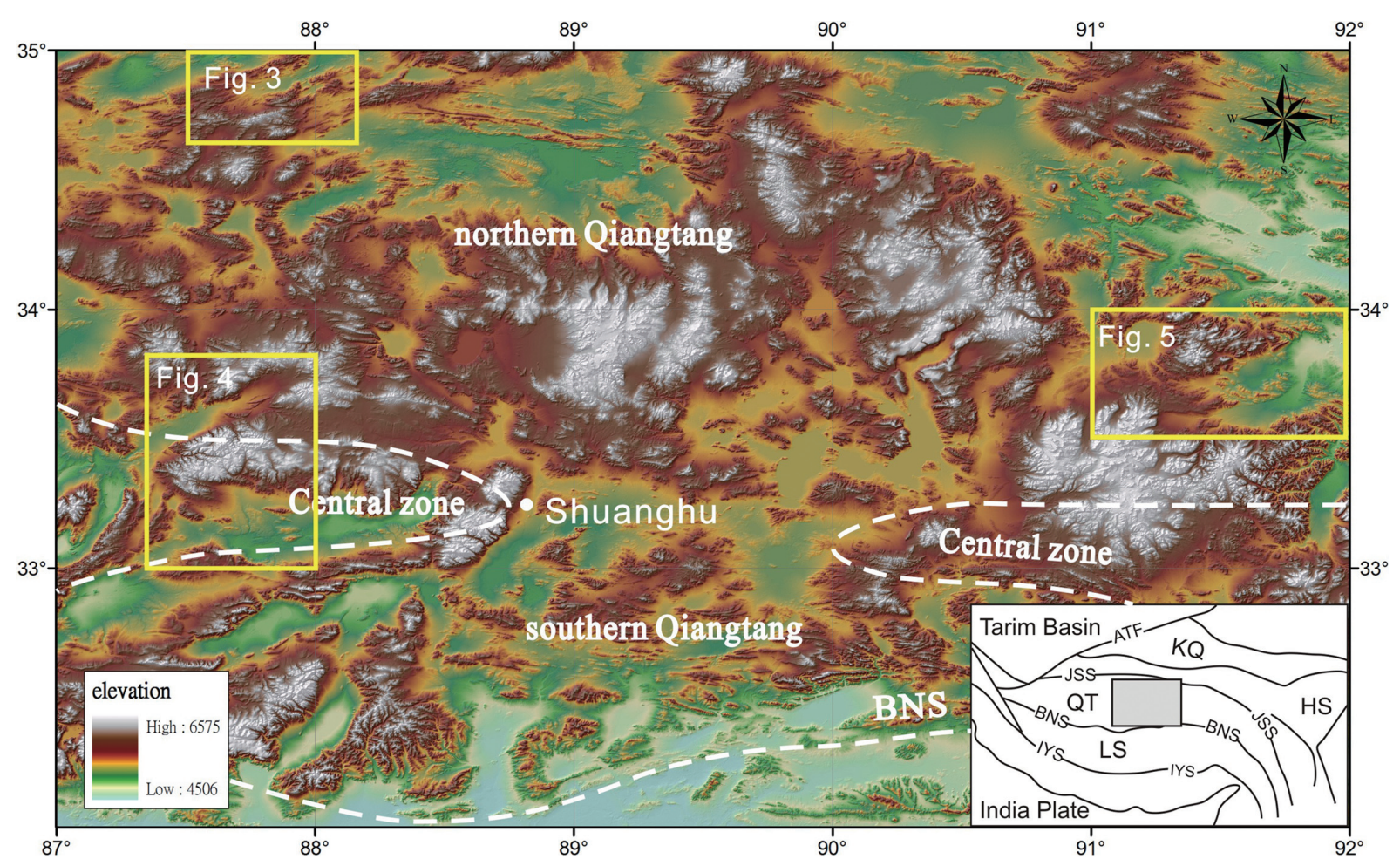

Fig. 1. Tectonic map of the Tibetan Plateau and the Digital elevation model (DEM) of the study area. The yellow box indicates the sampling location. Data for the DEM come from the Shuttle Rader Topography Mission (SRTM). The white lines represent the tectonic boundary. The Qiangtang block includes three sub-structure areas: northern Qiangtang, southern Qiangtang, and the Central zone. KQ: Kunlun-Qaidam block. HS: Hoh XilSongpan block. QT: Qiangtang block. LS: Lhasa block. JSS: Jinshajiang suture. BNS: Bangong-Nujiang suture. IYS: Indus-Yalung suture.

prospects. However, the characteristics of the late TriassicJurassic basin in Qiangtang has been a controversial issue and has had an enormous impact on the present direction of petroleum exploration in Qiangtang. (2) Did cooling events and tectonic exhumation occur in the Qiangtang block during the Qiangtang-Lhasa collision? Some studies have shown that the major exhumation in central Tibet occurred in the Cenozoic, but this may not be correct. A growing number of studies provide evidence for early exhumation during the late Mesozoic period (Murphy et al. 1997; Wang et al. 2008; Li et al. 2013). (3) How was the Qiangtang block exhumed during the Cenozoic period? Because the relevant data are lacking, the exhumation history remains unclear.

This study uses zircon fission-track (ZFT) and apatite fission-track (AFT) analysis of the Qiangtang block to answer the above questions and discusses the Late Mesozoic and Cenozoic geological evolution of northern Tibet. Fission track dating is a good thermo-chronological method for recording the annealing and cooling events caused by tectonic movement. The cooling and exhumation history can be reconstructed based on these fission-track dates, revealing the geological evolution of a site. Researchers have previously used fission track dating to resolve numerous geological problems in tectonothermal evolution (Fellin et al. 2006; Liu et al. 2009), collisional orogeny (Liu et al.
2000, 2001), magmatic activity (Yang et al. 1995, 2003), crust exhumation and mountain uplift (Jain et al. 2000; Garver et al. 2005; Wang et al. 2007; Lee et al. 2010), fault action (Tagami 2005; Yuan et al. 2006), and provenance studies (Carter and Moss 1999). Although many researchers have recently reported ZFT dates for the Tibetan Plateau, the thermo-chronological research on the Qiangtang block remains relatively scarce. This study provides important information to help understand the geological evolution of the Qiangtang block.

\section{GEOLOGICAL AND TECTONIC SETTING}

\subsection{Regional Tectonic Setting}

The Tibetan Plateau consists of a tectonic collage of continental terranes. From north to south, the Tibetan Plateau consists of the Kunlun-Qaidam block, the Hoh Xil-Songpan block, the Qiangtang block, the Lhasa block, and the Himalaya block. These terranes are separated by east-striking suture zones of late Paleozoic to Cenozoic age (Fig. 1) (Allègre et al. 1984; Dewey et al. 1988; Yin and Harrison 2000).

The Kunlun-Qaidam block is located in the northern part of the Tibetan Plateau and is bounded to the north by the Tarim block and to the south by the Hoh Xil-Songpan block. The Kunlun-Qaidam block primarily consists of 
Proterozoic basement rocks, middle Paleozoic granitic rocks, Devonian to Permian-Triassic carbonate rocks, and Triassic turbidite rocks (Jolivet et al. 2001). After the Late Triassic, continental deposits are dominant. The Mid-Jurassic slow cooling recorded by AFT (Jolivet et al. 2001) suggests there were no intense tectonic activities in this region. The Cretaceous to Cenozoic sediments are generally absent, and consist of fault depression deposits.

The Hoh Xil-Songpan block is located in the eastern part of the Tibetan Plateau and is mainly covered by Triassic flyschoid sediments. Paleozoic carbonate rocks and the Jurassic clastic rocks are relatively few and mainly appear in the eastern part of the Hoh Xil-Songpan block. The Kanding complex of 0.8 - 1 Ga may represent the basement rocks. Mesozoic granites and Tertiary granites are widely exposed in this region as a result of Triassic orogenetic movements and the Cenozoic India-Asia collision, respectively. The Triassic orogeny is contemporaneous with the Indosinian tectonism of Indochina and caused the fold deformation of the Triassic strata and the closure of the Paleo-Tethys Ocean (Roger et al. 2010).

During the Permo-Triassic period, the Kunlun, Hoh Xil-Songpan, and Qiangtang blocks were accreted to the southern margin of the Asia plate (Dewey et al. 1988). The Golmud granodiorite of approximately $240 \mathrm{Ma}$ (Roger et al. 2010) marked the onset of the subduction during the Early Triassic. The ophiolitic fragments along the Jinshajiang suture and the thick Triassic flysch of southern Kunlun are remnants of the Kunlun-Qiangtang collision (Harris et al. 1988). This collision resulted in a regional uplifting in the Jinshajiang suture, and the rocks cooled to below $300^{\circ} \mathrm{C}$ by the Late Triassic (Reid et al. 2005).

The Lhasa block is situated in the central-southern part of the Tibetan Plateau. The zircon U-Pb age of $787 \pm 9 \mathrm{Ma}$ from the oldest metamorphic rocks indicates a Neoproterozoic crystalline basement exists in the Lhasa block (Hu et al. 2005). The Paleozoic sedimentary strata in the Lhasa block are rare and primarily consist of Carboniferous clastic rocks and Ordovician, Silurian, and Permian limestone. The Triassic strata consist of limestone and volcanic rocks and are mainly exposed in the southern margin of the Lhasa block. The Jurassic rocks are characterized by clastic rocks and ophiolitic assemblages. The Cretaceous strata are widely exposed in the Lhasa block, indicating detrital deposition (Leier et al. 2007).

In the Late Jurassic-early Cretaceous period, the Qiangtang and Lhasa blocks collided along the BangongNujiang suture (Matte et al. 1996; Yin and Harrison 2000). This collision resulted in volcanic activity and changed the depositional facies from marine to nonmarine in the Banggong-Nujiang zone (Kapp et al. 2007).

The Indus-Yalung suture is the boundary between the Indian Plate and the Lhasa Terrane. The India-Asia collision at approximately 52 - 40 Ma (e.g., Searle et al. 1997;
Rowley 1998) resulted in the closure of the Yalung-Zangpo suture zone and the surface uplift of Tibet. The huge volume of Cenozoic igneous rocks in this area is also attributed to the India-Asia collision in Tibet (Wanming 1991; Arnaud et al. 1993; Tapponnier et al. 2001).

\subsection{Tectonic Setting of the Study Area}

Based on geophysical data, depositional characteristics, and surface geology, the Qiangtang block is usually divided into three units: the northern, central, and southern zones (Fig. 1) (Wang et al. 2001; Zhao et al. 2001; Wang et al. 2004, 2009). The ancient metamorphic crystalline basement of the Qiangtang block consists of gneiss containing sillimanite and kyanite, which are widely exposed along the central zone and have yielded a U-Pb SHRIMP zircon age of approximately 1780 - $1666 \mathrm{Ma}$ (Wang and Wang 2001; Tan et al. 2009; Wang et al. 2009). Based on sedimentary characteristics, the stratigraphic contact, and the degree of deformation and metamorphism, the sediments covering the Qiangtang block can be classified into four structural layers (Fig. 2): Devonian to Permian, Lower Triassic to Upper Triassic, upper Triassic to Jurassic, and Cretaceous to Tertiary. These four layers correspond to four different development stages of the Qiangtang block: a marginal basin, a foreland basin, passive continental margin rifting and a depression basin, and a fault depression. The Qiangtang-Asia collision ended the Neopaleozoic marginal basin formation and caused the initiation of the Triassic foreland basin. During the Norian Age, most parts of the Qiangtang block were uplifted, and paleo-weathering occurred widely in the area (Wang et al. 2004, 2009; Wang et al. 2007; Fu et al. 2010). The paleo-weathering crusts marked the end of the Triassic foreland basin (Fu et al. 2010). The onset and end of the Jurassic passive continental margin rifting and depression basin were controlled by the opening and closing of the Banggong-Nujiang Ocean, respectively. Because of the subduction and collision of the Lhasa-Qiangtang block, the Qiangtang block entered a fault-depression evolution stage during the Late Jurassic and Early Cretaceous (Zhang et al. 2009). During the Cenozoic India-Asia collision, the elevation of the Qiangtang block gradually increased and it became a plateau.

\subsection{Stratigraphic Features}

The Late Paleozoic strata are dominated by marine carbonate deposits and unconformably overlap with the Pre-Devonian metamorphic basement (Fig. 2). The Triassic strata consist mainly of the Kanglu, Kangnan, Xiaochaka, and Nadigangri formations. The first 3 formations are characterized by shallow marine clastic rocks and represent the Triassic foreland basin deposits (Wang et al. 2009). The Nadigangri Formation unconformably overlaps with the 


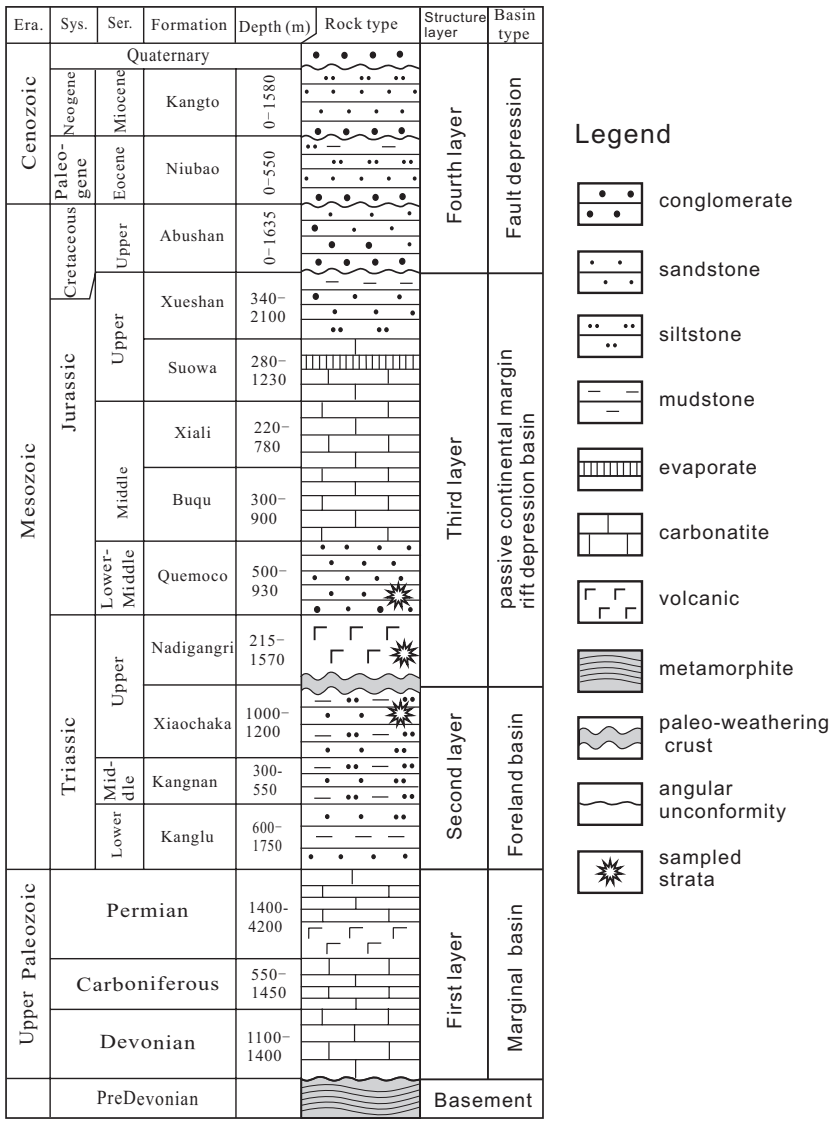

Fig. 2. Stratigraphic column and the evolution of basin characteristics in the Qiangtang block (modified by Wang et al. 2009). The strata depths were calculated from the field outcrops.

Xiaochaka Formation and consists of Late Triassic volcanic and volcanic-clastic rocks that have a U-Pb SHRIMP zircon age of approximately 220 - $205 \mathrm{Ma}$ (Wang et al. 2009; Fu et al. 2010). The Nadigangri Formation marks the start of the Late Triassic to Jurassic rifting and depression basin. The widely exposed Jurassic strata mainly consist of the Quemoco, Buqu, Xiali, Suowa, and Xueshan formations, which represent the Jurassic depression-basin deposits and consist of lower clastic rocks, middle carbonate rocks, and upper evaporate rocks and clastic rocks. The Cretaceous to Tertiary strata exhibit a combination of fluvial and lacustrine deposition.

To show the Late Mesozoic to Cenozoic tectonic evolution, especially the thermochronological responses to the Qiangtang-Lhasa and India-Asia collisions, this study uses the Late Triassic Xiaochaka, Nadigangri, and Early-Middle Jurassic Quemoco formations as the sampling strata in the Qiangtang block (Figs. 2, 3, 4, and 5). There are three main reasons for this sampling approach: (1) these formations were relatively widely exposed in the Qiangtang block; (2) as detrital rocks and volcanic-clastic rocks, these formations contain sufficient zircon and apatite minerals to conduct the experimental measurements; and (3) the rocks are old enough to record the cooling events induced by the Qiangtang-Lhasa and India-Asia collisions.

\section{SAMPLING AND ANALYSES}

\subsection{Sampling}

Fourteen samples were collected from the Xiaochaka, Nadigangri, and Quemoco formations (Table 1). The rock types of these samples vary from sandstone and rhyolite to tuff. Samples were taken from different sites in Qiangtang: four samples from the northern part of northern Qiangtang (Q1, 2, 3, and 4; see Fig. 3), two samples from the southern part of northern Qiangtang (Q5 and 6; see Fig. 4), one sample from the central zone of Qiangtang (Q7; see Fig. 4), two samples from the northern part of southern Qiangtang (Q8 and 9; see Fig. 4), and five samples from the central part of northern Qiangtang (Q10, 11, 12, 13, and 14; see Fig. 5). The elevation of all samples was measured using a portable GPS instrument.

\subsection{Laboratory Processing}

The individual mineral selection and fission-track dating were carried out at the China University of Geosciences. Conventional crushing, magnetic, and heavy liquid separation techniques were used to recover apatite and zircon fractions from the rock samples. The fission-track ages of the zircons and apatites were determined by the external detector method (Hurford and Green 1983). Apatite grains were mounted in epoxy resin and polished to expose the internal grain surface. Spontaneous tracks were revealed by etching using $6.6 \% \mathrm{HNO}_{3}$ for $30 \mathrm{~s}$ at $25^{\circ} \mathrm{C}$. The zircons were mounted on Teflon discs, ground and polished, and etched in a eutectic mixture of $\mathrm{NaOH}$ and $\mathrm{KOH}$ (Gleadow et al. 1976) at $210^{\circ} \mathrm{C}$ for 12 - $15 \mathrm{~h}$ (Yamada et al. 1995, 1998; Tagami and Shimada 1996). The muscovite external detectors were etched in $40 \% \mathrm{HF}$ for $20 \mathrm{~min}$ at $25^{\circ} \mathrm{C}$ to reveal the induced fission tracks. All samples were irradiated using a thermal-neutron nuclear reactor at the China Institute of Atomic Energy, Beijing. The ages of all samples were calculated using the Zeta calibration method (Hurford and Green 1983; Hurford 1990), with Zeta values of $85.4 \pm 4$ for ZFT and $389.4 \pm 19.2$ for AFT. Fission tracks and track lengths were counted and measured using an OLYMPUS microscope with a 100× immersion objective. Table 1 lists the analytical data, with the ages given with an error of $\pm 1 \sigma$.

\section{RESULTS}

\subsection{Zircon Fission-Track Results}

The fourteen zircon samples yielded a wide range of central ages ranging from $199 \pm 18$ to $54 \pm 8 \mathrm{Ma}$ (Table 1). The chi-square probability of a sample is a good indicator of 


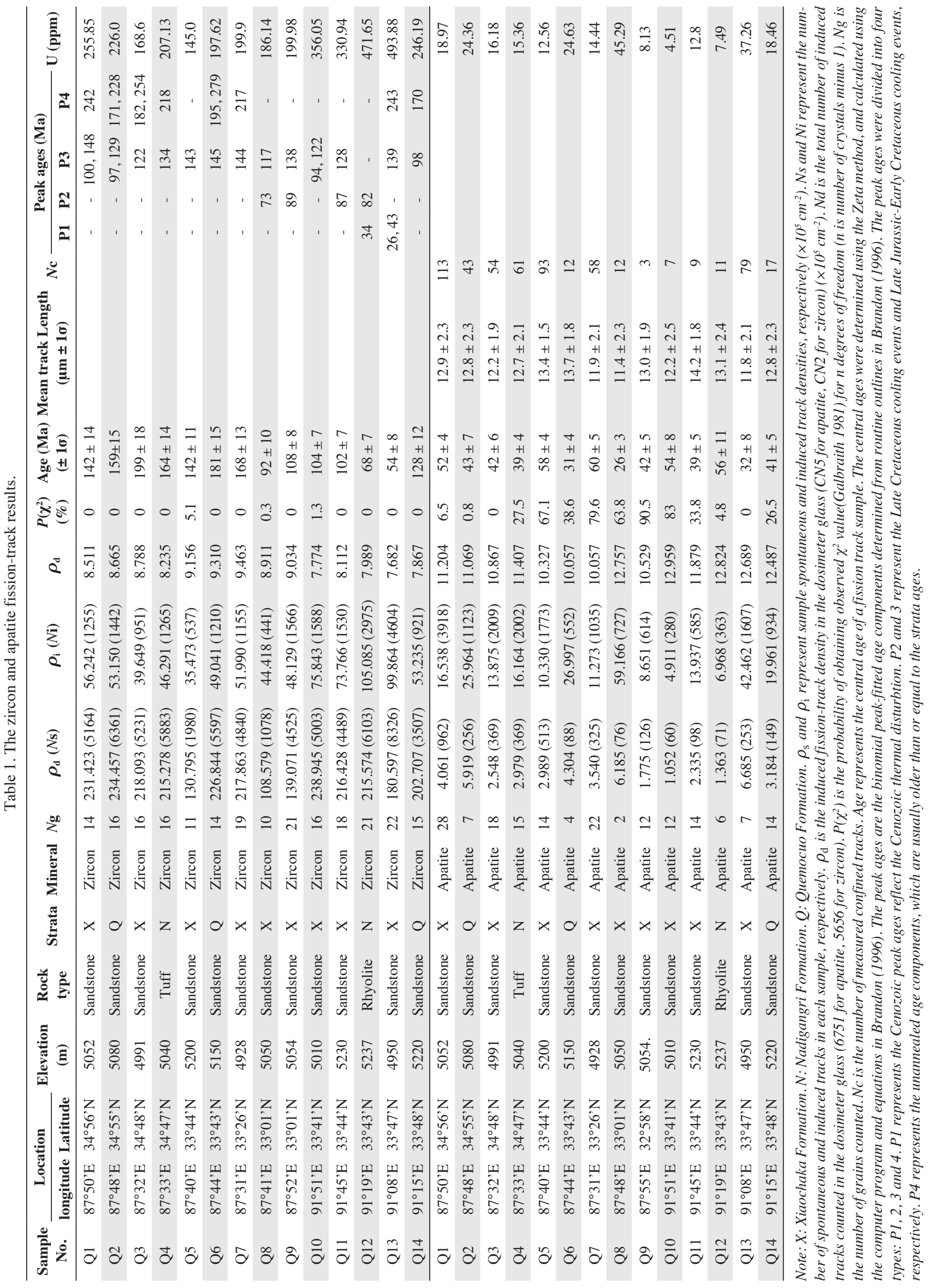




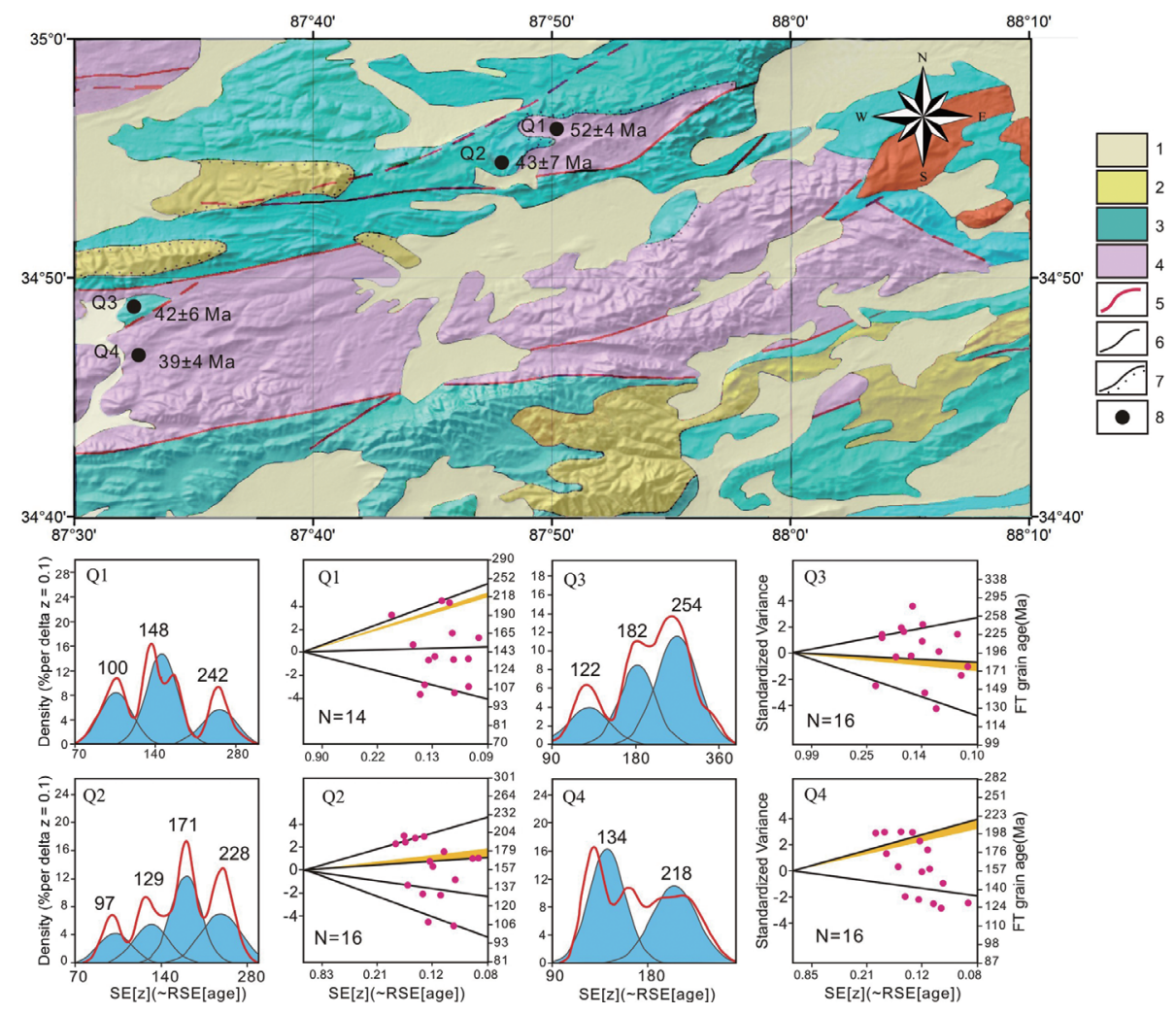

Fig. 3. Geological sketch map and the binomial peak-fitting results (after Brandon, 1996) of the ZFT samples from the northern part of northern Qiangtang. 1: Quaternary. 2: Tertiary. 3: Jurassic. 4: Triassic. 5: Fault line. 6: Strata boundary. 7: Unconformity. 8: Sampled location. In the geological sketch map, the black spots represent the sample location, and the sample number and the AFT ages are situated on the left and the right of them. In the binomial peak-fitting results, the left columns are the radial plots, and the right columns are the probability density plots. On the radial plots, dots represent ZFT grain ages and black lines represent individual peaks. The orange line represents the strata age. $\mathrm{N}$ is the number of the zircon grains. The solid black lines in the probability density plots represent the observed grain-age distribution, and yellow areas represent individual peaks.
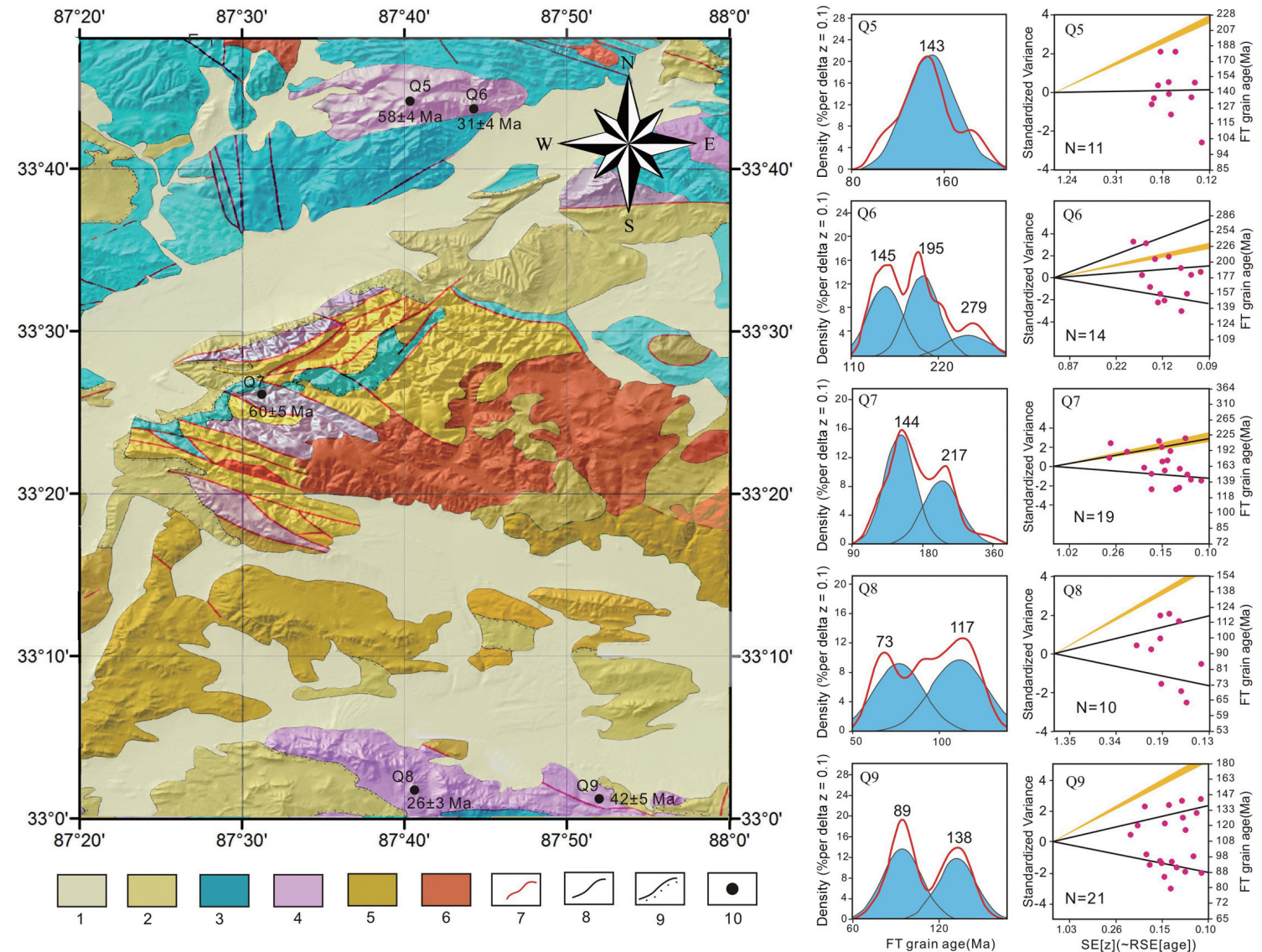

Fig. 4. Geological sketch map and the binomial peak-fitting results of the ZFT samples from the central zone of the Qiangtang block. 1: Quaternary. 2: Tertiary. 3: Jurassic. 4: Triassic. 5: Permian. 6: Mesozoic granites. 7: Fault line. 8: Strata boundary. 9: Unconformity. 10: Sampled location. 

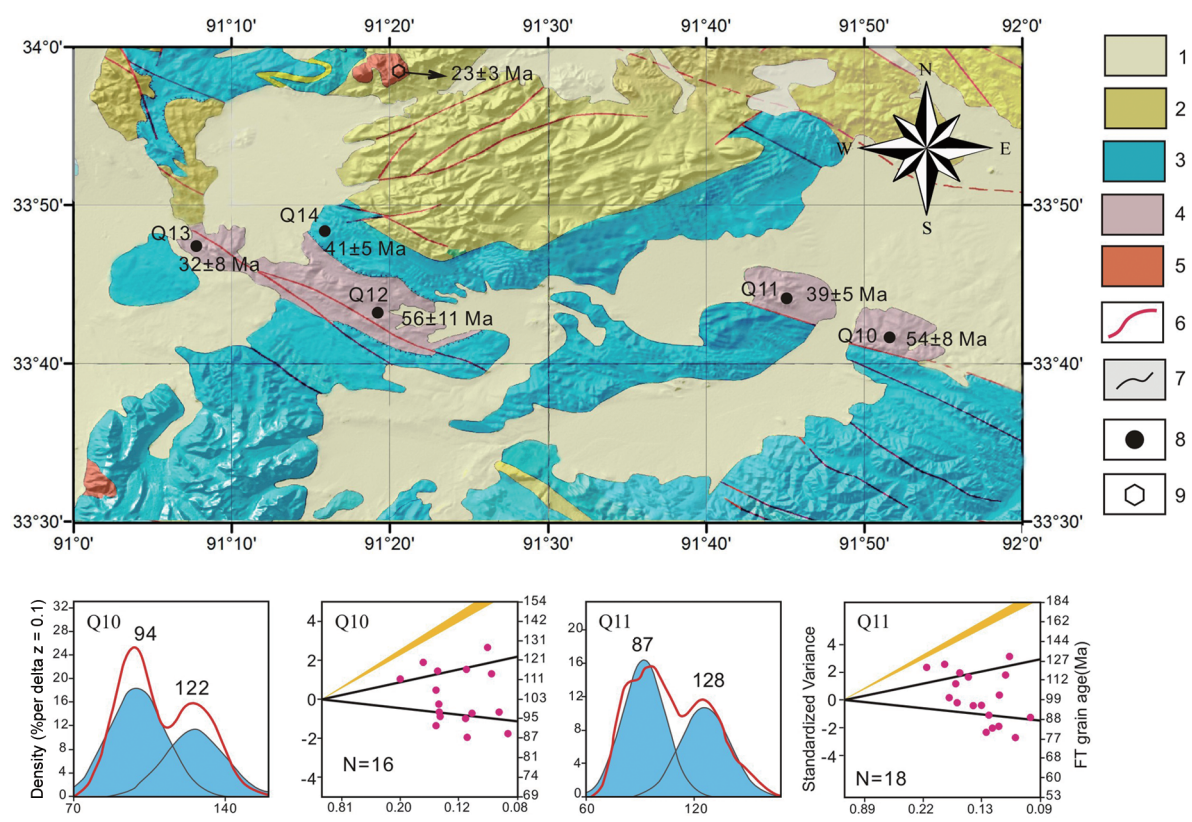

Fig. 5. Geological sketch map and the binomial peak-fitting results of the ZFT samples from the central part of northern Qiangtang. 1: Quaternary. 2: Tertiary. 3: Jurassic. 4: Triassic. 5: Cenozoic volcanics. 6: Fault line. 7: Strata boundary. 8: Sampled location. 9: The zircon U-Pb age of the Cenozoic volcanics.
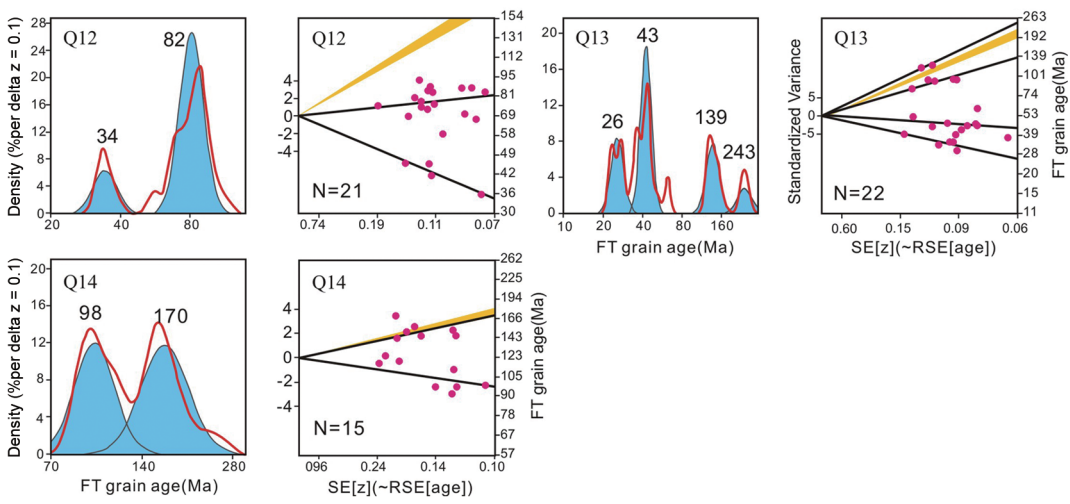

grain age $(\mathrm{Ma})$

whether the single-grain ages of a sample are homogeneous. If the single-grain age distributions pass the $\chi^{2}$ test, they are considered homogeneous (Galbraith and Green 1990). Thirteen ZFT samples (except for sample Q5) failed the $\chi^{2}$ test, indicating that they contain heterogeneous single-grain ages. Therefore, the central age is only an average age of the grains in each sample; it cannot represent a cooling event and is virtually meaningless (Fellin 2006). To better evaluate the geological significance of these data, the grain ages of each sample must be decomposed into a set of grain-age components or peaks. At present, the best method are the binomial peak-fitting methods of Galbraith and Green (1990) and Brandon (1996). Using these methods, this study obtains the best-fit peak ages of the ZFT ages and divides them into four groups: P1, 2, 3, and 4 ( Table 1 and Figs. 3, 4, and 5).

Previous studies show that many factors (including radiation damage, $\mathrm{U}$ concentration, time, temperature, cooling rate, and pressure) can affect the annealing properties of ZFT (Bernet and Garver 2005). Of these factors, radiation damage has the greatest effect. Zircon grains exposed to significant radiation have a low annealing temperature and are called low retentive zircons (LRZs). Zircons with low radiation damage have a high annealing temperature and are called high retentive zircons (HRZs) (Garver et al. 2005). The effective annealing temperatures of the LRZs and HRZs represent the upper and lower bounds of the partial annealing zone (PAZ) of ZFT, respectively. Therefore, a fully annealed ZFT sample will have only one peak age when quickly passing through the PAZ of ZFT and variable peak ages when slowly passing through the PAZ of ZFT. In previous studies, the temperatures of the PAZ for the ZFT are incompatible. For simplification, this study uses $\sim 300-180^{\circ} \mathrm{C}$ as the PAZ ZFT temperature range.

\subsection{Apatite Fission-Track Results}

The central ages of the fifteen apatite samples range from $60 \pm 5$ to $26 \pm 3 \mathrm{Ma}$ (Table 1 and Figs. 3, 4, and 5). All the central ages of the AFT samples are lower than their strata ages, suggesting they were fully annealed after deposition. The central ages of most of the samples range from 55 to 34 $\mathrm{Ma}$, and the average age is approximately $43 \mathrm{Ma}$. Therefore, 
the main cooling event occurred during the Eocene. Almost all the AFT samples (except Q2, 3, 12, and 13) passed the $\chi^{2}$ test, indicating a relatively rapid Cenozoic cooling rate.

To interpret the AFT data accurately, the samples with adequate numbers of track lengths $(>50)$ and single populations of grain ages were modeled using the annealing model of Ketcham et al. (1999). To avoid introducing artifacts, all the measured tracks must be confined tracks and all the confined tracks must be countered in the fission-track analysis. We used a starting point of $\sim 80 \mathrm{Ma}$ at $120 \pm 40^{\circ} \mathrm{C}$ in the AFT modeling because the maximum individual-grain ages of most samples were between 65 and $80 \mathrm{Ma}$. A temperature of $\sim 110-60^{\circ} \mathrm{C}$ delineates the AFT partial annealing zone, defined as the temperature interval in which the majority of track length shortening takes place. The present temperature was also set to a constant value of $20^{\circ} \mathrm{C}$, and 10000 paths were modeled for each plot (Fig. 6).

\section{DISCUSSION}

\subsection{Jurassic Annealing}

The peak ages of six ZFT samples (Q5, 8, 9, 10, 11, and 12) in this study are younger than their strata ages, indicating the ZFT underwent full annealing and was reset after the strata or rock formation. The peak ages of the other eight ZFT samples (Q1, 2, 3, 4, 6, 7, 13, and 14) are equal to or younger or older than their strata ages, indicating a partial annealing after the strata or rock formation. All the samples in the study area show evidence that different degrees of annealing occurred after formation because the individualgrain ages would be older than the depositional age if a sample did not undergo annealing after deposition (Tagami and O'Sullivan 2005).

An annealing event is generally caused either by volcanism or by deep burial. Judging by the Late Jurassic to Early Cretaceous cooling ages, the annealing of the ZFT must have taken place before that time and continued until the Late Jurassic. According to the geological survey of the Qiangtang block, there are relatively few Late Jurassic igneous rocks, and they are mainly located in the central zone and marginal area. Hence, the Late Jurassic annealing event of the ZFT may have been caused only by the deep burial. With the measured PAZ temperature of $\sim 240-180^{\circ} \mathrm{C}$, the present average surface temperature of $20^{\circ} \mathrm{C}$, and the borehole
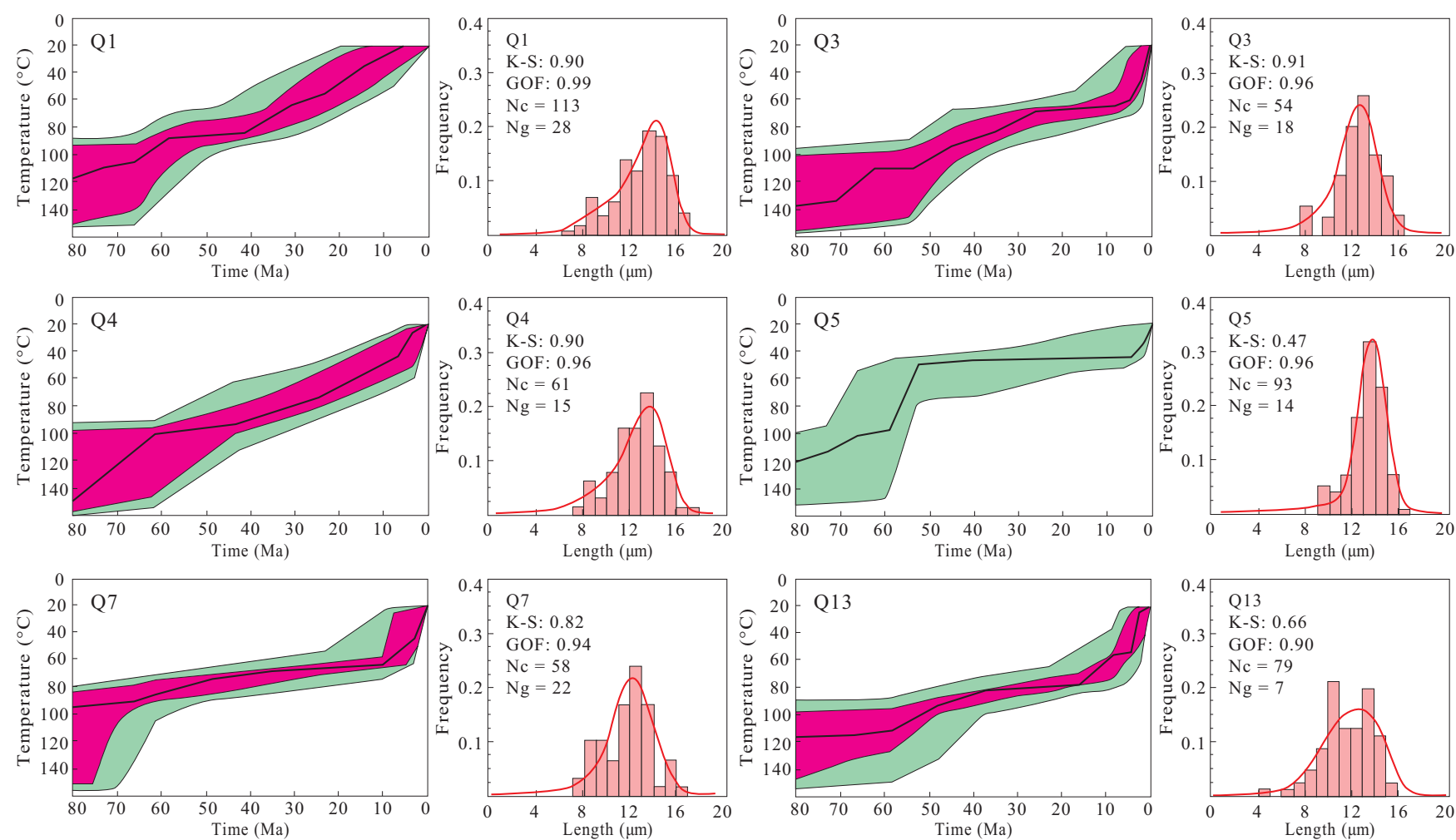

Fig. 6. Modeling diagrams of the apatite fission-track data. Modeled time-temperature paths for six apatite samples, computed with AFTSolve program. The black lines show 'best-fit' curves, and the green area and magenta area represent 'acceptable' thermal history range and 'good' thermal history range, respectively. 'K-S test' is the goodness-of-fit between the model and measured track lengths. 'GOF' is the goodness-of-fit between the model and measured ages. The modeled thermal history is 'acceptable' when both the model AFT age and the model track length distribution matched their measured counterparts with a level of confidence of 5\% or greater. The modeled thermal history is deemed to be 'good' when both the model AFT age and the model track length distribution match their measured counterparts with a level of confidence of $50 \%$ or greater. $\mathrm{Ng}$ is the number of grains counted. $N \mathrm{c}$ is the number of measured confined tracks. 
gradient of $25^{\circ} \mathrm{C} \mathrm{km}^{-1}$, the calculated burial depth of the samples may have reached or exceeded $6.4-11.2 \mathrm{~km}$ during the Late Jurassic. Because the sampled strata are situated on the depositional bottom of the Jurassic marine Qiangtang Basin, the burial depth of the samples represents the Jurassic depositional thickness, which is nearly consistent with the result of the stratum thickness statistics ( $7000 \mathrm{~m}$; see Fig. 2).

Three ZFT samples (Q10, 11, and 12) from the central part of northern Qiangtang were fully annealed in the Late Jurassic; however, four samples (Q1, 2, 3, and 4) from the northern part of northern Qiangtang were only partially annealed, which suggests that the burial depth of the former was greater than that of the latter. The maximum peak ages of the fully reset samples (Q10, 11, and 12) are all early Cretaceous, indicating that the samples reached their deepest burial depths and were fully annealed in the late Jurassic or before, then cooled below $180^{\circ} \mathrm{C}$ in the early Cretaceous. Hence, the annealing differences of the samples reflect the differences of the late Triassic-Jurassic depositional depth. This means the late Triassic-Jurassic depositional depth of the former is greater than that of the latter, and the late Triassic-Jurassic basin type cannot be a foreland basin in the Qiangtang block because the late Triassic-Jurassic depositional depth of the northern part of northern Qiangtang would be much greater than that of the central part of northern Qiangtang if the late Triassic-Jurassic Qiangtang basin is a foreland basin (see Wang et al. 2001; Zhang et al. 2009). The ZFT result is consistent with that of the lithofacies palaeogeography study. From north to south, the Jurassic sedimentary environments are beach, carbonate-platform, and continental shelf in Qiangtang (Wang et al. 2004, 2009). Therefore, the central thickness is greater than that of the northern part in the northern Qiangtang for the Jurassic deposit, and the Jurassic basin of Qiangtang must be a passive-marginal basin. This study has settled one of the most hotly debated questions in the petroleum exploration of the Mesozoic Qiangtang basin: Was Qiangtang a foreland basin or a passive marginal basin during the late Triassic-Jurassic period? The response to this question can help determine the favorability of the petroleum exploration zones in Qiangtang and suggest some directions to consider for oil and gas exploration in the study region.

\subsection{Late Jurassic-Cretaceous Exhumation}

During the Late Jurassic-Early Cretaceous, the Qiangtang block likely collided with the Lhasa block along the Bangong-Nujiang suture (Kapp et al. 2003; Murphy and Yin 2003; Wang et al. 2007; Murphy et al. 2010). This collision resulted in a series of granitic intrusions in the BangongNujiang suture. Examples include the Pangduo intrusions of $123.8 \pm 1.8-129.6 \pm 7.8 \mathrm{Ma}(\mathrm{U}-\mathrm{Pb}$ zircon dating; Wuet al.2004) and the Dangxiong-Sangxiong intrusions of $\sim 130-120 \mathrm{Ma}$
(Wang et al. 2007). The ${ }^{40} \mathrm{Ar} /{ }^{39} \mathrm{Ar}$ data of $104 \pm 2 \mathrm{Ma}$ from the southern Kunlun block and 165 - 110 Ma from the southcentral Tibetan Plateau are the direct results of the Qiangtang-Lhasa collision (Yuan et al. 2006; Wang et al. 2007). The Qiangtang-Lhasa collision also resulted in a depositional facies change from marine to nonmarine environments and major denudation during the Early Cretaceous in Qiangtang (Wang et al. 2004; Kapp et al. 2007).

Sample Q5 has only one peak age of $143 \mathrm{Ma}$, indicating that it quickly cooled below $\sim 180^{\circ} \mathrm{C}$ in the late Jurassic-early Cretaceous. Four samples (Q8, 9, 10, and 11) have two peak ages (ranging from 73 to $138 \mathrm{Ma}$ ), indicating they underwent a relatively slow cooling process from $\sim 300$ to $180^{\circ} \mathrm{C}$ during the Cretaceous. The time interval between P2 and 3 is approximately $45 \mathrm{Ma}$, which reflects the time of residence in the PAZ of ZFT (Figs. 4 and 5).

Seven samples (Q1, 2, 3, 4, 6, 7, and 14) have the youngest peak ages ranging from the Late Jurassic to Early Cretaceous, indicating they underwent partial annealing and cooled below the upper temperature $\left(\sim 180^{\circ} \mathrm{C}\right)$ of the ZFT during that time (Figs. 3 and 5). The relatively young peak ages (i.e., $148 \mathrm{Ma}$ from sample Q1) represent the time when the relatively resistant zircons cooled below their annealing temperature.

Most of the ZFT samples contain Early Cretaceous peak ages, indicating early exhumation and cooling events in Qiangtang. The Early Cretaceous peak ages are the youngest peak ages in most of the samples (except Q8, 9, 11,12 , and 13), indicating that these samples had cooled below $\sim 180^{\circ} \mathrm{C}$ by the end of the Early Cretaceous.

During the Late Cretaceous, the reactivation of the Bangong-Nujiang suture caused volcanic activity and crustal shortening and thickening in central Tibet (Yin et al. 1995; Murphy et al. 1997; DeCelles et al. 2007; Li et al. 2013). The crust of the Qiangtang block was significantly thickened because of ongoing underthrusting by the Lhasa block (Kapp et al. 2007). The Late Cretaceous peak ages from four ZFT samples (Q8, 9, 11, and 12) indicate the Late Cretaceous exhumation of the Qiangtang block.

In conclusion, all the ZFT samples from Qiangtang cooled below the partial annealing zone of ZFT $\left(\sim 300-180^{\circ} \mathrm{C}\right)$ in the Late Cretaceous (before $73 \mathrm{Ma}$ ). The peak ages of P2 and 3 of the ZFT samples are the thermochronological record of the Late Jurassic-Cretaceous ( 148 - $73 \mathrm{Ma})$ exhumation in the Qiangtang block. This means the burial depth of the samples was less than $6.4 \mathrm{~km}$ at the end of the Cretaceous and that the exhumation thickness was greater than $2000 \mathrm{~m}$ during the Cretaceous.

Late Mesozoic exhumation of the Qiangtang block is evidenced by an increasing number of studies, such as crustal shortening analysis (Murphy et al. 1997), ${ }^{40} \mathrm{Ar} /{ }^{39} \mathrm{Ar}$ dating (Wang et al. 2007), structural deformation and sedimentation analysis (Kapp et al. 2007; Wang et al. 2008), and volcanic activity studies ( $\mathrm{Li}$ et al. 2013). The current study 
is the first to report ZFT data for the Qiangtang block, and the results reconfirm the Late Jurassic-Cretaceous cooling events and tectonic exhumation.

\subsection{Cenozoic Exhumation}

As a result of the India-Asia collision, uplift in Tibet occurred. Thermochronology studies suggest that cooling events occurred during the Cenozoic in the Qiangtang block (Wang et al. 2001, 2007; Wang and Zhao et al. 2008).

The Cenozoic peak ages (P1) in ZFT samples Q12 and 13 in this study do not represent the exhumation of the Qiangtang block. Instead, these ages can be attributed to thermal disturbance from Cenozoic volcanism because there are no overlapping regions between the Cenozoic peak (namely, P1) and the Mesozoic peak (namely, P2). Generally, there would be overlapping regions between the $\mathrm{Ce}$ nozoic and Mesozoic peaks if a sample had been located in the PAZ since the Mesozoic. In addition, the Cenozoic peak ages only exist in the samples from the central part of northern Qiangtang and are consistent with the zircon U-Pb ages of the Cenozoic volcanics from the central part of northern Qiangtang (Fig. 5). Therefore, the P1 ages are the result of the thermal disturbance of the Cenozoic volcanism, and the $\mathrm{P} 2$ ages of samples Q12 and 13 may represent the time when the samples were exhumed through the PAZ of ZFT and cooled below $\sim 180^{\circ} \mathrm{C}$.

The central AFT ages range from $26 \pm 3$ to $60 \pm 5 \mathrm{Ma}$ (Table 1), indicating that the Cenozoic exhumation of Qiangtang began in the Eocene and that the samples were subsequently cooled below the AFT closure temperature again $\left(\sim 110^{\circ} \mathrm{C}\right)$. This means that the samples cooled from $\sim 180$ to $\sim 110^{\circ} \mathrm{C}$ between $\mathrm{P} 2(73-89 \mathrm{Ma})$ and $65 \mathrm{Ma}$. This cooling event may have been caused by the collision of the Lhasa-Gangdese block (Searle et al. 1999). Direct evidence of the Lhasa-Gangdese collision is the $\sim 90$ - 50 Ma granitic intrusions distributed from east to west along the Gangdese belt (Pan and Ding 2004). This collision also led to the denudation of the regional Cretaceous land basin sediments in Qiangtang.

According to the inverse modeling for six apatite samples (Fig. 6), the Cenozoic exhumation process can be classified into three phases. Before $\sim 50 \mathrm{Ma}$, the buried depths of most of the samples reached more than $3.6 \mathrm{~km}$. At $\sim 50 \mathrm{Ma}$, all the samples cooled below $\sim 110^{\circ} \mathrm{C}$ due to denudation and entered the AFT PAZ (Fig. 6). This cooling event is called the "early Cenozoic cooling", and its age is consistent with the collision between the Indian continental crust and the Asian plate along the Indus-Yalung suture in the PaleoceneEocene ( $\sim 55$ - $45 \mathrm{Ma}$ ) (Dewey et al. 1988). Thus, the early Cenozoic cooling may have been caused by the India-Asia collision.

From $\sim 50$ to $20 \mathrm{Ma}$, the Qiangtang block began to be exhumed slowly with a minor cooling rate of $\sim 0.5-1^{\circ} \mathrm{C} \mathrm{Myr}^{-1}$.
However, nearly all the samples passed through the partial annealing of AFT $\left(\sim 110-60^{\circ} \mathrm{C}\right)$ and cooled below $60^{\circ} \mathrm{C}$ at $\sim 20 \mathrm{Ma}$ (Fig. 6). After the India-Asia collision, the weak tectonic stress led to the slow exhumation process and extension and thinning of the lithosphere beneath the Qiangtang block and produced the 40 - $30 \mathrm{Ma}$ adakitic volcanic rocks in this block (Liu et al. 2008).

After $\sim 20-10 \mathrm{Ma}$, the samples experienced a rapid cooling rate of $4-6^{\circ} \mathrm{C} \mathrm{Myr}^{-1}$ (Fig. 6). This cooling was likely caused by the India-Himalaya underthrusting. The granitic intrusions of approximately $24-22 \mathrm{Ma}$ along the Indus-Yalung suture are the products of the India-Himalaya underthrusting (Yin et al. 1995). A study of the post-collisional magmas also supports the rapid uplift of the western Tibetan Plateau after $\sim 20 \mathrm{Ma}$ (Chung et al. 1998). The AFT data from the Kunlun-Qaidam block also reflect a rapid cooling event during the Late Cenozoic (Jolivet et al. 2001; Yuan et al. 2006). Moreover, the AFT and the (U-Th)/He ages from southeastern Tibet indicate a rapid cooling and river incision between 13 and $9 \mathrm{Ma}$ (Clark et al. 2005).

However, the Late Cenozoic exhumation was not recorded by the former AFT samples from Qiangtang (Wang et al. 2007). Therefore, the results presented here confirm the Late Cenozoic cooling and the exhumation in the Qiangtang block. In addition, according to the AFT modeling, the late Cenozoic exhumation rate was most rapid during the Cenozoic period and may be the main reason why most of the Cenozoic strata were eroded and the Jurassic strata were widely exposed at the surface in the Qiangtang block.

\section{CONCLUSION}

The fission track dating of 14 zircon samples and 14 apatite samples in this study helps understand the exhumation history of the Qiangtang block from the Mesozoic to Cenozoic. The peak ZFT ages and the inverse modeling of AFT lead to the following conclusions:

(1) The late Triassic-Jurassic depositional depth of the central part of northern Qiangtang is greater than that of the northern part of northern Qiangtang, indicating that the late Triassic-Jurassic Qiangtang basin may not be a foreland.

(2) The collision between Qiangtang and Lhasa resulted in a large-scale inversion and a change from a marine to a non-marine depositional environment in the Qiangtang block during the Cretaceous period. The Qiangtang block then began to be exhumed, and the burial depth of the samples was less than $6.4 \mathrm{~km}$ at the end of the Cretaceous. The exhumation thickness exceeded 2000 $\mathrm{m}$ during the Cretaceous.

(3) Because of the India-Asiacollision, the Cenozoic exhumation of Qiangtang began in the Eocene. From 50 to $20 \mathrm{Ma}$, the Qiangtang block had a relatively slow cooling rate of $\sim 0.5-1^{\circ} \mathrm{C} \mathrm{Ma}^{-1}$. After $\sim 20-10 \mathrm{Ma}$, almost all the 
samples entered a rapid cooling stage with a cooling rate of $4-6^{\circ} \mathrm{C} \mathrm{Ma}^{-1}$ because of the India-Himalaya underthrusting.

(4) Using the inverse modeling of the AFT data, this study is the first to confirm the existence of the Late Cenozoic cooling and exhumation process in the Qiangtang block.

Acknowledgments This study was supported by the National Natural Science Foundation of China (No. 40972087) and the National Oil and Gas Special Project: Strategic Investigation and Geological Survey on Tibet Oil and Gas Resources (No. XQ-2009-01). We thank Roufei Chen and Guozhen Zhang for their assistance with writing. We thank Wanming Yuan and Yuanxi Li for critical reviews and suggestions, which helped us improve the paper.

\section{REFERENCES}

Allègre, C. J., V. Courtillot, P. Tapponnier, A. Hirn, M. Mattauer, C. Coulon, J. J. Jaeger, J. Achache, U. Schärer, J. Marcoux, J. P. Burg, J. Girardeau, R. Armijo, C. Gariépy, C. Göpel, T. Li, X. Xiao, C. Chang, G. Li, B. Lin, J. Teng, N. Wang, G. Chen, T. Han, X. Wang, W. Den, H. Sheng, Y. Cao, J. Zhou, H. Qiu, P. Bao, S. Wang, B. Wang, Y. Zhou, and R. Xu, 1984: Structure and evolution of the Himalaya-Tibet orogenic belt. $\mathrm{Na}$ ture, 307, 17-22, doi: 10.1038/307017a0. [Link]

Arnaud, N. O., M. Brunel, J. M. Cantagrel, and P. Tapponnier, 1993: High cooling and denudation rates at Kongur Shan, Eastern Pamir (Xinjiang, China) revealed by ${ }^{40} \mathrm{Ar} /{ }^{39} \mathrm{Ar}$ alkali feldspar thermochronology. Tectonics, 12, 1335-1346, doi: 10.1029/93TC00767. [Link]

Bernet, M. and J. I. Garver, 2005: Fission-track analysis of detrital zircon. Rev. Mineral. Geochem., 58, 205-237, doi: 10.2138/rmg.2005.58.8. [Link]

Brandon, M. T., 1996: Probability density plot for fissiontrack grain-age samples. Radiat. Meas., 26, 663-676, doi: 10.1016/S1350-4487(97)82880-6. [Link]

Carter, A. and S. J. Moss, 1999: Combined detrital-zircon fission-track and U-Pb dating: A new approach to understanding hinterland evolution. Geology, 27, 235238, doi: 10.1130/0091-7613(1999)027<0235:CDZFT $\mathrm{A}>2.3 . \mathrm{CO} ; 2$. [Link]

Chung, S. L., C. H. Lo, T. Y. Lee, Y. Zhang, Y. Xie, X. Li, K. L. Wang, and P. L. Wang, 1998: Diachronous uplift of the Tibetan plateau starting $40 \mathrm{Myr}$ ago. Nature, 394, 769-773, doi: 10.1038/29511. [Link]

Clark, M. K., M. A. House, L. H. Royden, K. X. Whipple, B. C. Burchfiel, X. Zhang, and W. Tang, 2005: Late Cenozoic uplift of southeastern Tibet. Geology, 33, 525-528, doi: 10.1130/G21265.1. [Link]

DeCelles, P. G., P. Kapp, L. Ding, and G. E. Gehrels, 2007: Late Cretaceous to middle Tertiary basin evolution in the central Tibetan Plateau: Changing environments in response to tectonic partitioning, aridification, and regional elevation gain. Geol.Soc. Am. Bull., 119, 654680, doi: 10.1130/B26074.1. [Link]

Dewey, J. F., R. M. Shackleton, C. Chang, and Y. Sun, 1988: The tectonic evolution of the Tibetan Plateau. Phil. Trans. R. Soc. Lond. A, 327, 379-413, doi: 10.1098/ rsta.1988.0135. [Link]

Ding, L., P. Kapp, Y. Yue, and Q. Lai, 2007: Postcollisional calc-alkaline lavas and xenoliths from the southern Qiangtang terrane, central Tibet.Earth Planet.Sc. Lett., 254, 28-38, doi: 10.1016/j.eps1.2006.11.019. [Link]

Fellin, M. G., J. A. Vance, J. I. Garver, and M. Zattin, 2006: The thermal evolution of Corsica as recorded by zircon fission-tracks. Tectonophysics, 421, 299-317, doi: 10.1016/j.tecto.2006.05.001. [Link]

Fu, X., J. Wang, F. Tan, M. Chen, and W. Chen, 2010: The Late Triassic rift-related volcanic rocks from eastern Qiangtang, northern Tibet (China): Age and tectonic implications. Gondwana Res., 17, 135-144, doi: 10.1016/j.gr.2009.04.010. [Link]

Fu, X., J. Wang, Y. Zeng, F. Tan, X. Feng, and W. Chen, 2011a: Geochemistry of platinum group elements in marine oil shale from the Changshe Mountain area (China): Implications for modes of occurrence and origins. Int. J. Coal Geol., 86, 169-176, doi: 10.1016/j. coal.2011.01.002. [Link]

Fu, X., J. Wang, Y. Zeng, F. Tan, and J. He, 2011b: Geochemistry and origin of rare earth elements (REEs) in the Shengli River oil shale, northern Tibet, China. Chem. Erde-Geochem., 71, 21-30, doi: 10.1016/j. chemer.2010.07.003. [Link]

Galbraith, R. F. and P. F. Green, 1990: Estimating the component ages in a finite mixture. Int. J. Radiat. Appl. Instrum., Part D, 17, 197-206, doi: 10.1016/13590189(90)90035-V. [Link]

Garver, J. I., P. W. Reiners, L. J. Walker, J. M. Ramage, and S. E. Perry, 2005: Implications for timing of Andean uplift from thermal resetting of radiation-damaged zircon in the Cordillera Huayhuash, northern Peru. $J$. Geol., 113, 117-138, doi: 10.1086/427664. [Link]

Gleadow, A. J. W., A. J. Hurford, and R. D. Quaife, 1976: Fission track dating of zircon: Improved etching techniques. Earth Planet. Sci. Lett., 33, 273-276, doi: 10.1016/0012-821X(76)90235-1. [Link]

Guo, Z., Y. Li, Z. Nan, H. Ye, 2008: Relationship between deformation structure and petroleum accumulation and preservation, Qiangtang Basin, Tibet. Petrol. Explor. Develop., 35, 563-568, doi: 10.1016/S18763804(09)60089-6. [Link]

Guynn, J., P. Kapp, G. E. Gehrels, L. Ding, 2012: U-Pb geochronology of basement rocks in central Tibet and paleogeographic implications. J. Asian Earth Sci., 43, 23-50, doi: 10.1016/j.jseaes.2011.09.003. [Link]

Harris, N. B. W., R. Xu, C. L. Lewis, and C. Jin, 1988: 
Plutonic rocks of the 1985 Tibet geotraverse, Lhasa to Golmud. Philos. T. R. Soc. A, 327, 145-168, doi: 10.1098/rsta.1988.0124. [Link]

Hu, D., Z. Wu, W. Jiang, Y. Shi, P. Ye, and Q. Liu, 2005: SHRIMP zircon $\mathrm{U}-\mathrm{Pb}$ age and $\mathrm{Nd}$ isotopic study on the Nyainqêntanglha Group in Tibet. Sci. China Ser. D, 48, 1377-1386, doi: 10.1360/04yd0183. [Link]

Hurford, A. J., 1990: Standardization of fission track dating calibration: Recommendation by the Fission Track Working Group of the I.U.G.S. Subcommission on Geochronology. Chem. Geol., 80, 171-178, doi: 10.1016/0168-9622(90)90025-8. [Link]

Hurford, A. J. and P. F. Green, 1983: The zeta age calibration of fission-track dating. Chem. Geol., 41, 285-317, doi: 10.1016/S0009-2541(83)80026-6. [Link]

Jain, A. K., D. Kumar, S. Singh, A. Kumar, and N. Lal, 2000: Timing, quantification and tectonic modelling of Pliocene-Quaternary movements in the NW Himalaya: Evidence from fission track dating. Earth Planet. Sci. Lett., 179, 437-451, doi: 10.1016/S0012821X(00)00133-3. [Link]

Jolivet, M., M. Brunel, D. Seward, Z. Xu, J. Yang, F. Roger, P. Tapponnier, J. Malavieille, N. Arnaud, and C. Wu, 2001: Mesozoic and Cenozoic tectonics of the northern edge of the Tibetan plateau: Fission-track constraints. Tectonophysics, 343, 111-134, doi: 10.1016/S00401951(01)00196-2. [Link]

Kapp, P., A. Yin, C. E. Manning, T. M. Harrison, M. H. Taylor, and L. Ding, 2003: Tectonic evolution of the early Mesozoic blueschist-bearing Qiangtang metamorphic belt, central Tibet. Tectonics, 22, doi: 10.1029/2002TC001383. [Link]

Kapp, P., P. G. DeCelles, G. E. Gehrels, M. Heizler, and L. Ding, 2007: Geological records of the Lhasa-Qiangtang and Indo-Asian collisions in the Nima area of central Tibet. Geol. Soc. Am. Bull., 119, 917-933, doi: 10.1130/B26033.1. [Link]

Ketcham, R. A., R. A. Donelick, and W. D. Carlson, 1999: Variability of apatite fission-track annealing kinetics: III. Extrapolation to geological time scales. Am. Mineral., 84, 1235-1255.

Lee, Y., X. Xu, and X. Tan, 2010: Mountain-building mechanism of the Longmenshan fault. Recent Dev. World Seismol., 6, doi: 10.3969/j.issn.0235-4975.2010.06.002. (in Chinese) [Link]

Leier, A. L., P. Kapp, G. E. Gehrels, and P. G. DeCelles, 2007: Detrital zircon geochronology of Carboniferous-Cretaceous strata in the Lhasa terrane, Southern Tibet. Basin Res., 19, 361-378 , doi: 10.1111/j.13652117.2007.00330.x. [Link]

Li, Y., C. Wang, H. Yi, H. Shi, J. Lin, L. Zhu, and X. Li, 2001: Fill Models of in the Qiangtang Composite Foreland Basin in Qinghai-Xizang Plateau, China. Acta Sedimentol. Sin., 19, 20-27, doi: 10.3969/j.issn.1000-
0550.2001.01.004. (in Chinese with English abstract) [Link]

Li, Y., Q. Wu, X. Tian, R. Zeng, R. Zhang, and H. Li, 2006: Crustal structure beneath Qiangtang and Lhasa terrane from receiver function. Acta Seismol. Sin., 19, 633-642, doi: 10.1007/s11589-006-0633-z. [Link]

Li, Y., J. He, C. Wang, M. Santosh, J. Dai, Y. Zhang, Y. Wei, and J. Wang, 2013: Late Cretaceous K-rich magmatism in central Tibet: Evidence for early elevation of the Tibetan plateau? Lithos, 160-161, 1-13, doi: 10.1016/j.lithos.2012.11.019. [Link]

Liu, S., R. Hu, C. Feng, H. Zou, C. Li, X. Chi, J. Peng, H. Zhong, L. Qi, Y. Qi, and T. Wang, 2008: Cenozoic high $\mathrm{Sr} / \mathrm{Y}$ volcanic rocks in the Qiangtang terrane, northern Tibet: Geochemical and isotopic evidence for the origin of delaminated lower continental melts. Geol.Mag., 145, 463-474, doi: 10.1017/S0016756808004548. [Link]

Liu, S. S., U. Weber, U. A. Glasmacher, Z. Q. Xu, and G. A. Wagner, 2009: Fission track analysis and thermotectonic history of the main borehole of the Chinese Continental Scientific Drilling project. Tectonophysics, 475, 318-326, doi: 10.1016/j.tecto.2009.03.015. [Link]

Liu, T. K., Y. G. Chen, W. S. Chen, and S. H. Jiang, 2000: Rates of cooling and denudation of the Early Penglai Orogeny, Taiwan, as assessed by fission-track constraints. Tectonophysics, 320, 69-82, doi: 10.1016/ S0040-1951(00)00028-7. [Link]

Liu, T. K., S. Hsieh, Y. G. Chen, W. S. Chen, 2001: Thermokinematic evolution of the Taiwan oblique-collision mountain belt as revealed by zircon fission track dating. Earth Planet. Sci. Lett., 186, 45-56, doi: 10.1016/ S0012-821X(01)00232-1. [Link]

Matte, Ph., P. Tapponnier, N. Arnaud, L. Bourjot, J. P. Avouac, Ph. Vidal, Q. Liu, Y. Pan, and Y. Wang, 1996: Tectonics of Western Tibet, between the Tarim and the Indus. Earth Planet. Sci. Lett., 142, 311-330, doi: 10.1016/0012-821X(96)00086-6. [Link]

Mo, X., Z. Zhao, J. Deng, M. Flower, X. Yu, Z. Luo, Y. Li, S. Zhou, G. Dong, D. Zhu, and L. Wang, 2006: Petrology and geochemistry of postcollisional volcanic rocks from the Tibetan plateau: Implications for lithosphere heterogeneity and collision-induced asthenospheric mantle flow. Geol. Soc. Am. Bull., 409, 507-530, doi: 10.1130/2006.2409(24). [Link]

Murphy, M. A. and A. Yin, 2003: Structural evolution and sequence of thrusting in the Tethyan fold-thrust belt and Indus-Yalu suture zone, southwest Tibet. Geol. Soc. Am. Bull., 115, 21-34, doi: 10.1130/0016-7606(20 03) $115<0021$ :SEASOT $>2.0 . C O ; 2$. [Link]

Murphy, M. A., A. Yin, T. M. Harrison, S. B. Dürr, Z. Chen, F. J. Ryerson, W. S. F. Kidd, X. Wang, and X. Zhou, 1997: Did the Indo-Asian collision alone create the Tibetan plateau? Geology, 25, 719-722, doi: 10.1130/009 1-7613(1997)025<0719:DTIACA >2.3.CO;2. [Link] 
Murphy, M. A., V. Sanchez, and M. H. Taylor, 2010: Syncollisional extension along the India-Asia suture zone, south-central Tibet: Implications for crustal deformation of Tibet. Earth Planet. Sci. Lett., 290, 233-243, doi: 10.1016/j.eps1.2009.11.046. [Link]

Pan, G. T. and J. Ding, 2004: Geologic Map (1:1500000) of Tibetan Plateau and its Adjacent Areas, China Cartographic Publishing House, Chengdu. (in Chinese)

Reid, A. J., C. J. L. Wilson, D. Phillips, and S. Liu, 2005: Mesozoic cooling across the Yidun Arc, central-eastern Tibetan Plateau: A reconnaissance ${ }^{40} \mathrm{Ar} /{ }^{39} \mathrm{Ar}$ study. Tectonophysics, 398, 45-66, doi: 10.1016/j.tecto.2005. 01.002. [Link]

Rodgers, A. J. and S. Y. Schwartz, 1998: Lithospheric structure of the Qiangtang Terrane, northern Tibetan Plateau, from complete regional waveform modeling: Evidence for partial melt. J. Geophys. Res., 103, 71377152, doi: 10.1029/97JB03535. [Link]

Roger, F., M. Jolivet, and J. Malavieille, 2010: The tectonic evolution of the Songpan-Garzê (North Tibet) and adjacent areas from Proterozoic to Present: A synthesis. J. Asian Earth Sci., 39, 254-269, doi: 10.1016/j.jseaes.2010.03.008. [Link]

Rowley, D. B., 1998: Minimum age of initiation of collision between India and Asia north of Everest based on the subsidence history of the Zhepure Mountain section. $J$. Geol., 106, 220-235, doi: 10.1086/516018. [Link]

Searle, M. P., R. R. Parrish, K. V. Hodges, A. Hurford, M. W. Ayres, and M. J. Whitehouse, 1997: Shisha Pangma leucogranite, South Tibetan Himalaya: Field relations, geochemistry, age, origin, and emplacement. J. Geol., 105, 295-318, doi: 10.1086/515924. [Link]

Searle, M. P., M. A. Khan, J. E. Fraser, S. J. Gough, and M. Q. Jan, 1999: The tectonic evolution of the KohistanKarakoram collision belt along the Karakoram Highway transect, north Pakistan. Tectonics, 18, 929-949, doi: 10.1029/1999TC900042. [Link]

Tagami, T., 2005: Zircon fission-track thermochronology and applications to fault studies. Rev. Mineral. Geochem., 58, 95-122, doi: 10.2138/rmg.2005.58.4. [Link]

Tagami, T. and C. Shimada, 1996: Natural long-term annealing of the zircon fission track system around a granitic pluton. J. Geophys. Res., 101, 8245-8255, doi: 10.1029/95JB02885. [Link]

Tagami, T. and P. B. O'Sullivan, 2005: Fundamentals of fission-track thermochronology. Rev. Mineral. Geochem., 58, 19-47, doi: 10.2138/rmg.2005.58.2. [Link]

Tan, F., J. Wang, X. Fu, M. Chen, and B. Du, 2009: U-Pb zircon SHRIMP age of metamorphic rocks from the basement of the Qiangtang Basin, northern Tibet, and its geological significance. Acta Petrol. Sin., 25, 139146. (in Chinese with English abstract)

Tapponnier, P., Z. Xu, F. Roger, B. Meyer, N. Arnaud, G. Wittlinger, and J. Yang, 2001: Oblique stepwise rise and growth of the Tibet plateau. Science, 294, 16711677, doi: 10.1126/science.105978. [Link]

Unsworth, M., W. Wei, A. G. Jones, S. Li, P. Bedrosian, J. Booker, S. Jin, M. Deng, and H. Tan, 2004: Crustal and upper mantle structure of northern Tibet imaged with magnetotelluric data. J. Geophys. Res., 109, B02403, doi: 10.1029/2002JB002305. [Link]

Wang, C., Yi, H., Li, Y., Deng, B., and Liu, D., 2001: The Gological Evolution and Prospective Oil and Gas Assessment of the Qiangtang Basin in Northern Tibet Plateau, Geological Publishing House, Beijing, 210-400. (in Chinese)

Wang, C., X. Zhao, Z. Liu, P. C. Lippert, S. A. Graham, R. S. Coe, H. Yi, L. Zhu, S. Liu, and Y. Li, 2008: Constraints on the early uplift history of the Tibetan Plateau. P. Natl. A. Sci., 105, 4987-4992, doi: 10.1073/ pnas.0703595105. [Link]

Wang, G. and C. Wang, 2001: Disintegration and age of basement metamorphic rocks in Qiangtang, Tibet, China. Sci. China Ser. D, 44, 86-93, doi: 10.1007/ BF02911975. [Link]

Wang, J., F. W. Tan, Y. L. Li, Y. T. Li, M. Chen, C. S. Wang, Z. J. Guo, X. L. Wang, B. W. Du, and Z. F. Zhu, 2004: The Potential of the Oil and Gas Resources in Major Sedimentary Basins on the Qinghai-Xizang (Tibet) Plateau, Geological Publishing House, Beijing, 10-300. (in Chinese)

Wang, J., X. Fu, W. Chen, Z. Wang, F. Tan, M. Chen, and J. Zhuo, 2008: Chronology and geochemistry of the volcanic rocks in Woruo Mountain region, Northern Qiangtang depression: Implications to the Late Triassic volcanic-sedimentary events. Sci. China Ser.D, 51, 194-205, doi: 10.1007/s11430-008-0010-y. [Link]

Wang, J., J. Ding, C. S. Wang, F. W. Tan, 2009: Potential Analysis and Geological Survey of the Hydrocarbon Resources in Tibetan Plateau, Geological Publishing House, Beijing, 1-69. (in Chinese)

Wang, Y., X. Zhang, L. Sun, and J. Wan, 2007: Cooling history and tectonic exhumation stages of the south-central Tibetan Plateau (China): Constrained by ${ }^{40} \mathrm{Ar} /{ }^{39} \mathrm{Ar}$ and apatite fission track thermochronology. J. Asian Earth Sci., 29, 266-282, doi: 10.1016/j.jseaes.2005.11.001. [Link]

Wanming, D., 1991: Cenozoic volcanism and intraplate subduction at the northern margin of the Tibetan Plateau. Chin. J. Geochem., 10, 140-152, doi: 10.1007/ BF02837714. [Link]

Wu,Z.H.,X.G.Meng,D.G.Hu, W.Jiang,P.S.Ye,D.G.Zhu, Q. S.Liu, X. D. Yang, Z . G. Shao, and Z. H. Wu, 2004: New results and major progress in regional geological survey of the Damxung County Sheet. Geol. Bull. China, 23, 484-491, doi: 10.3969/j.issn.1671-2552.2004. 05.014. (in Chinese with English abstract) [Link]

Yamada, R., T. Tagami, and S. Nishimura, 1995: Confined 
fission-track length measurement of zircon: Assessment of factors affecting the paleotemperature estimate. Chem. Geol., 119, 293-306, doi: 10.1016/00092541(94)00108-K. [Link]

Yamada, R., T. Yoshioka, K. Watanabe, T. Tagami, H. Nakamura, T. Hashimoto, and S. Nishimura, 1998: Comparison of experimental techniques to increase the number of measurable confined fission tracks in zircon. Chem. Geol., 149, 99-107, doi: 10.1016/S00092541(98)00037-0. [Link]

Yang, T. F., J. Tien, C. H. Chen, T. Lee, and R. S. Punongbayang, 1995: Fission-track dating of volcanics in the northern part of the Taiwan-Luzon Arc: Eruption ages and evidence for crustal contamination. J. Southeast Asian Earth Sci., 11, 81-93, doi: 10.1016/07439547(94)00041-C. [Link]

Yang, T.F., C. H.Chen, R.L. Tien, S.R.Song, and T. K. Liu, 2003: Remnant magmatic activity in the Coastal Range of East Taiwan after arc-continent collision: Fissiontrack data and ${ }^{3} \mathrm{He} /{ }^{4} \mathrm{He}$ ratio evidence. Radiat. Meas., 36, 343-349, doi: 10.1016/S1350-4487(03)00149-5. [Link]

Yin, A. and T. M. Harrison, 2000: Geologic evolution of the Himalayan-Tibetan orogen. Annu. Rev. Earth Planet. Sci., 28, 211-280, doi: 10.1146/annurev .earth.28.1.211. [Link]

Yin, A., M. A. Murphy, T. M. Harrison, S. B. Duerr, Z. Chen, X. Wang, X. Zhou, F. J. Ryerson, and W. S. F. Kidd, 1995: Significant crustal shortening in the Lhasa Block (southern Tibet) predates the Indo-Asian collision. Geol. Soc. Amer., 27, A-335.

Yuan, W., J. Dong, S. Wang, and A. Carter, 2006: Apatite fission track evidence for Neogene uplift in the eastern Kunlun Mountains, northern Qinghai-Tibet Plateau, China. J. Asian Earth Sci., 27, 847-856, doi: 10.1016/j. jseaes.2005.09.002. [Link]

Zhai, Q., C. Li, and X. Huang, 2007: The fragment of Paleo-Tethys ophiolite from central Qiangtang, Tibet:
Geochemical evidence of metabasites in Guoganjianian. Sci. China Ser. D, 50, 1302-1309, doi: 10.1007/ s11430-007-0051-7. [Link]

Zhai, Q., J. Wang, C. Li, and L. Su, 2010: SHRIMP U-Pb dating and $\mathrm{Hf}$ isotopic analyses of Middle Ordovician meta-cumulate gabbro in central Qiangtang, northern Tibetan Plateau. Sci. China Earth Sci., 53, 657-664, doi: 10.1007/s11430-010-0063-6. [Link]

Zhai, Q., B. M. Jahn, R. Y. Zhang, J. Wang, and L. Su, 2011: Triassic Subduction of the Paleo-Tethys in northern Tibet, China: Evidence from the geochemical and isotopic characteristics of eclogites and blueschists of the Qiangtang Block. J. Asian Earth Sci., 42, 1356-1370, doi: 10.1016/j.jseaes.2011.07.023. [Link]

Zhang, K. J., J. X. Cai, Y. X. Zhang, and T. P. Zhao, 2006: Eclogites from central Qiangtang, northern Tibet (China) and tectonic implications. Earth Planet. Sci. Lett., 245, 722-729, doi: 10.1016/j.eps1.2006.02.025. [Link]

Zhang, K. J., X. C. Tang, Y. Wang, and Y. X. Zhang, 2011: Geochronology, geochemistry, and $\mathrm{Nd}$ isotopes of early Mesozoic bimodal volcanism in northern Tibet, western China: Constraints on the exhumation of the central Qiangtang metamorphic belt. Lithos, 121, 167 175, doi: 10.1016/j.lithos.2010.10.015. [Link]

Zhang, S., C. Zhang, M. Hu, W. Gong, C. Xiao, A. Liu, and D. Lü, 2009: Base level change and depositional filling response of Jurassic in the Qiangtang Basin of Tibet. Sci. China Ser. D, 52, 143-151, doi: 10.1007/s11430009-5003-y. [Link]

Zhang, Z., Y. Deng, J. Teng, C. Wang, R. Gao, Y. Chen, and W. Fan, 2011: An overview of the crustal structure of the Tibetan plateau after 35 years of deep seismic soundings. J. Asian Earth Sci., 40, 977-989, doi: 10.1016/j.jseaes.2010.03.010. [Link]

Zhao, Z. Z., Y. T. Li, H. F. Ye, and Y. W. Zhang, 2001: Tectonic Characteristics and Basin Evolution of the Tibet Plateau, Science Press, Beijing, 1-300. (in Chinese with English abstract) 